більшість - 65 \%. До низького рівня було віднесено 23,2 \% респондентів, які виявляють низький інтерес до процесу творчої навчальної роботи над музичним твором, а тому вони фрагментарно виконували навчальне завдання, застосовуючи набуті знання та вміння.

Діагностичні зрізи рівнів сформованості вміння студентів творчо працювати над літературним текстом вокального твору були проведені в навчальних умовах - під час складання заліку з дисципліни «Постановка голосу», у процесі виконання студентами вокальних творів за навчальною програмою. Експертам було запропоновано оцінити ступінь здатності кожного студента до творчої роботи над літературним текстом вокального твору, що було здійснено самостійно у процесі підготовки до заліку. Оцінювання виступу студентів здійснювалось експертами за параметрами: яскраве представлення виконання вокального твору; чітка, ясна дикція під час співу; усвідомлена вимова слів; виділення головних слів під час співу; ступінь зображальності звучання головних слів вокального твору; динаміка розвитку композиційної лінії твору за допомогою донесення слухачу літературного тексту вокального твору; відчуття цілісності відтворення художньо-образного змісту; збереження характеру виконання твору після закінчення співу. До високого рівня було віднесено 7 \% студентів, які під час співу вокального твору продемонстрували свідомий погляд, звертаючись до уявного персонажу, чітку дикцію, емоційну наповненість кожного слова літературного тексту. До середнього рівня було віднесено 64 \% студентів, які під час співу виділяли головні слова літературного тексту в кульмінаційних фрагментах вокального твору, зрозуміло вимовляли слова, проте ці слова оцінювались експертами як «пусті», неусвідомлені самим студентом. Студенти, які виявили низький рівень (29\%), під час виконання вокального твору головну увагу звертали тільки на вчасний вдих, правильне виконання мелодійної лінії, витримку пауз, фермат. При цьому, вимова літературного тексту вокального твору була нечіткою, деякі слова були поза увагою студента.

\title{
Література
}

1. Карелин А. А. Психологические тесты в 2 т. / А. А. Карелин. - Москва : Гуманит. изд. центр «Владос», 2002. - Т. 1. - 312 с. 2. Лившиц В. Ю. Современная энциклопедия психологических тестов : 300 тестов / В. Ю. Лившиц. - Донецк : ООО ПКФ «БАО», 2005. 384 с. 3. Майковская Л. С. Артистизм учителя музыки: [учеб. пособие] / Л. С. Майковская. [2 изд. доп.]. - Москва : Моск. гос. ун-т культуры и искусств, 2005. - 74 с.

УДК 378.147:37.0011

Дар'я Кудренко

\section{РОЛЬ ДИФЕРЕНЦЙОВАНОГО НАВЧАННЯ У ФАХОВІЙ ПІДГОТОВЦІ СТУДЕНТІВ ХУДОЖНЬО-ГРАФІЧНИХ ФАКУЛЬТЕТІВ}

Кудренко Д. О. Роль диференційованого навчання у фаховій підготовці студентів художньо-графічних факультетів.

У статті проаналізовано роль та місце диференційованого підходу у фаховій підготовці майбутніх учителів образотворчого мистецтва, висвітлюється специфіка зовнішньої та внутрішньої диференціації навчального процесу; указано на важливість застосування внутрішньої диференціації для розкриття пізнавальних можливостей, вияву художніх здібностей студентів мистецьких спеціальностей.

Ключові слова: диференційоване навчання, внутрішня диференціація, студенти факультету мистецтв, навчальна діяльність, художній образ, художньо-творчі здібності. 
Кудренко Д. О. Роль дифференцированного обучения в профессиональной подготовке студентов художественно-графических факультетов.

В статье анализируются роль и место дифференцированного подхода в профессиональной подготовке будущих учителей изобразительного искусства, освещается специфика внешней и внутренней дифференциации учебного процесса; подчеркивается важность применения внутренней дифференциации для раскрытия познавательных возможностей, проявления художественных способностей студентов художественных специальностей.

Ключевые слова: дифференцированное обучение, внутренняя дифференциация, студенты факультета искусств, учебная деятельность, художественный образ, художественно-творческие способности.

Kudrenko D. O. The role of differentiated education in the vocational training of of art and graphic students.

The article analyzes the role of differentiated approach in the vocational training of future teachers of fine arts, highlights the specifics of external and internal differentiation of the educational process; emphasises the importance of internal differentiation for opening up educational opportunities, showing artistic abilities of art students.

Key words: differentiated education, internal differentiation, art students, educational activity, artistc image, art and creative skills.

Реформування вітчизняної вищої школи на засадах компетентнісного підходу спонукає теоретиків та практиків вищої педагогічної освіти до пошуку нових резервів забезпечення гарантованої якості фахової підготовки. Зовнішніми стимулами для таких пошуків стало прийняття Закону України «Про вищу освіту» (редакція від 01.01.2015), узгодженого з рекомендаціями ЄС, та розгортання процесів оптимізації мережі вищих навчальних закладів. Внутрішня підстава - потреба забезпечення якості фахової підготовки бакалаврів та магістрів вищих педагогічних закладів освіти, выдповідно до нових освітніх стандартів та загалом - якість освітньої діяльності, яка в сучасних нормативних документах визначається як «рівень організації освітнього процесу у вищому навчальному закладі, що відповідає стандартам вищої освіти, забезпечує здобуття особами якісної вищої освіти та сприяє створенню нових знань» [3].

Проблема забезпечення якості фахової підготовки студентів вищих навчальних закладів була в центрі уваги багатьох педагогів, дидактів вищої школи -С. Архангельського, С. Гончаренка, І. Кобиляцького, А. Кузьмінського, 3. Курлянд, В. Лозової та ін. Психологічні механізми здійснення навчальної діяльності студентів вищої школи висвітлено у працях Є. Ільїна, А. Крашеніннікова, І. Кулагіної, А. Петровського, В. Шпалінського, якими досліджено проблему адаптації студентів, активно вивчаються психологічні механізми пізнавальної діяльності студентів, психологічна структура навчальної діяльності, види навчальних дій, провідні чинники процесу навчання.

Десятиліття, що триває, відкриває нові горизонти наукових досліджень. Трансформацію наукових зусиль втілює вимога необхідності здійснення суб’єкт-суб’єктного підходу до відбору форм, методів, прийомів навчальної діяльності у вищій школі, формула «від абстрактного суб’єкта навчального процесу до конкретного студента - майбутнього фахівця певної галузі». Тож вектор сучасних наукових досліджень спрямовано в площину фахової підготовки студентів певного профілю. 
Мета статmі - висвітлили роль і місце диференційованого навчання у фаховій підготовці майбутніх учителів образотворчого мистецтва. Завдання публікації: з'ясувати особливості зовнішньої та внутрішньої диференціації у процесі фахової підготовки студентів художньо-графічних факультетів, конкретизувати чинники, які $є$ спонукальними для застосування внутрішньої диференціації. Процесуальні особливості підготовки публікації зумовлені добором та застосуванням відповідних методів: вивчення, аналіз дидактичних робіт з проблеми застосування диференційованого навчання; теоретичний аналіз та узагальнення ідей, що містяться в сучасних дисертаційних дослідженнях, об’єктне поле яких окреслене проблемами фахової підготовки студентів художньо-графічних факультетів; метод конкретизації методичних матеріалів; метод спостереження за ходом навчальної діяльності студентів художньо-графічних факультетів.

Художньо-графічний напрям фахової підготовки студентів вищих педагогічних навчальних закладів за своїми організаційно-структурними особливостями зумовлює широке поле для застосування диференційованого навчання. Різні аспекти організації та здійснення фахової підготовки студентів мистецьких спеціальностей висвітлено в роботах О. Гайдамаки, А. Дейнеки, О. Кайдановської, С. Коновець, Є. Шорохова, Л. Масол, В. Щербини. Методичні пошуки цих науковців детерміновані загальними ідеями стосовно ролі та місця мистецтв у всебічному гармонійному розвитку та становленні особистості (І. Зязюн, О. Кібрик, О. Отич, Б. Неменський, О. Рудницька). Незважаючи на суттєвий науково-теоретичний та методичний доробок, безумовно, мають рацію ті дослідники, які стверджують, що зміст і методика викладання образотворчого мистецтва у вищому педагогічному навчальному закладі дещо відстають від тенденцій, які окреслилися в останні роки в педагогіці вищої школи та в мистецькому житті суспільства. Занепокоєння з приводу якості сучасної мистецької освіти висловлюють на сторінках наукових, науково-популярних видань педагоги, діячі науки i культури. Стурбованість фахівців станом справ викликана появою значної кількості авторських програм 3 образотворчого мистецтва, які демонструють найрізноманітніші підходи до викладання цієї дисципліни в загальноосвітній школі та пропагують нові методичні прийоми. Здебільшого, ці програми не підкріплюються досвідом реальної експериментальної перевірки в шкільних умовах, не враховують індивідуальних особливостей учнів певної вікової категорії. Деякі 3 них переобтяжені теоретичною інформацією загально мистецького, культурологічного плану, яка відірвана від завдань формування практичних умінь та навичок тих, хто навчається. Тому й процес підготовки майбутнього вчителя образотворчого мистецтва певною мірою ускладнюється внаслідок такого невиправданого (з методичної та психолого-педагогічної точок зору) розмаїття.

Свого часу Н. Тализіна зазначала: «Сьогодні приватні методики навчання повинні розвиватися не стільки шляхом узагальнення педагогічного досвіду, скільки експериментально: спираючись на досягнення фундаментальних наук, проектувати науково обгрунтовані системи навчання та їх експериментально перевіряти. Тільки на цьому шляху методика викладання як наука зможе випереджати практику навчання, вести ії за собою» [8, с. 3]. Ця думка дослідниці в реаліях сьогодення має винятково важливе значення. Ї̈̈ варто взяти на озброєння укладачам численних програм, без чого сучасний «методичний плюралізм» може негативно позначитися на результатах фахової підготовки майбутніх учителів образотворчого мистецтва. Уважаємо, що частково можна розв'язати цю проблему (певною мірою нівелювати окремі її негативні наслідки) шляхом застосування резервів диференційованого підходу в процесі фахової підготовки студентів художньографічних факультетів. 
Як відомо, диференційований підхід - це загальний методичний принцип навчання, що передбачає використання різноманітних методів і прийомів навчання, залежно від мети, виду навчальної діяльності, етапів навчання [4, с. 77]. Власне термін «диференційоване навчання» (від лат. differentia - «різниця» [1]) тлумачиться по-різному. На суто організаційних підставах диференціації наголошує С. Гончаренко, визначаючи цей процес як «розподіл навчальних планів і програм... виокремлення й посилення провідних, профілюючих навчальних предметів, яке не суперечить принципу єдності навчання, оскільки при цьому забезпечуються встановлені державні стандарти» [1, с. 95].

Визначення характеризують зовнішню диференціацію навчальної діяльності студентів, яка $€$ домінантною саме для студентів факультету мистецтв, оскільки тут превалюють індивідуалізовані форми навчальної діяльності - робота в майстернях, групова діяльність тощо. У дидактиці вищої школи досліджено особливості застосування як зовнішньої, так і внутрішньої диференціації. Остання переважно розуміється як така організація навчального процесу, за якої враховуються індивідуальні особливості суб’єктів учіння і тому $\epsilon$ певною мірою дотичною до поняття «індивідуалізація навчання». За визначенням М. Скаткіна, диференційоване навчання відбувається там і тоді, коли враховуються індивідуальні відмінності суб’єктів учіння. Саме резерви внутрішньої диференціації варто активізовувати в процесі викладання студентам факультету мистецтв таких фахових дисциплін, як «Живопис», «Графіка», «Композиція», «Рисунок».

Безпосередні спостереження за особливостями здійснення навчальної діяльності студентів факультету мистецтв Криворізького педагогічного інституту ДВНЗ «Криворізький національний університет» під час вивчення фахових дисциплін, дозволили виявити низку негативних тенденцій. А саме: сприйняття студентами мистецької дійсності на буденному рівні; існування певного розриву між знаннями й практичним їх застосуванням, особливо в нових навчальних ситуаціях. Як наслідок, у студентів виявляється недостатньо сформованим перенос умінь і навичок на нові види образотворчої й художньо-професійної діяльності, знання зазвичай носять формальний характер, контекстне мислення не розвинуте. Такий стан справ не сприяє розвитку образотворчих здібностей студентів, перешкоджає їх професіоналізації.

Ідеям проектування спільного навчального та художньо-творчого процесу на основі диференційованого підходу співзвучні пошуки художників-педагогів, що прокладають нові шляхи до досягнення цілісності системи художньої освіти та фахової підготовки майбутніх учителів образотворчого мистецтва. У циклі бесід «Мистецтво-Культура-Освіта» видатний художник-педагог Б. Неменський стверджує: «Проблеми зв’язку теорії з практикою для будь-якого педагога особливо важливі - потрібно розуміти, чому ти робиш те чи те, чому тобі рекомендують робити це, потім інше, а не навпаки, чому оптимальним є пропонований педагогом спосіб поєднання завдань» [7, с. 10].

Особливості застосування внутрішньої диференціації в навчальному процесі на художньо-графічних факультетах зумовлені потребою здійснювати таку організацію навчання, яка дає можливість кожному студентові оволодіти певною порцією навчального матеріалу за рівнем, не нижче базового, залежно від їх творчих здібностей та індивідуальних особливостей. Також внутрішня диференціація навчального процесу спонукає викладача послуговуватися такими критеріями оцінки навчальної діяльності студентів, як-от:

- індивідуальні зусилля студента в оволодінні навчальним матеріалом;

- творче застосування набутих умінь та навичок у різних видах мистецької діяльності; 
- гнучкість, нетривіальність, нешаблонність мислення студентів, що виявляється під час виконання різновидів практичних (творчих) завдань.

Наприклад, система диференційованих завдань, які застосовуються в ході вивчення студентами навчального курсу «Композиція», сприяє виробленню в майбутніх учителів образотворчого мистецтва певної програми «композиційної поведінки», яка складається 3 цілісного сприйняття натури, вмінь переводити зоровий (або уявний ідеальний) образ на мову зображення тощо. При цьому «перехід» образу в зображення на площині пов'язаний із знаходженням певної системи просторових відношень та взаємозв’язків і нерідко спирається на мовну характеристику образу [8]. I хоча цей процес носить індивідуальний характер, він відбувається за типологічними, диференційованими ознаками.

Як справедливо зауважували у свій час М. Скаткін та М.Шахмаєв, у науковопедагогічній літературі доволі обачно використовується термін «диференціація за здібностями» [2], та для студентів факультету мистецтв саме цей різновид внутрішньої диференціації висувається на перший план в останні семестри фахової підготовки. Його сутність зводиться до практичного перевтілення сукупності пізнавальних інтересів, схильностей, мистецьких пріоритетів, художніх здібностей, а інколи й таланту, у стійкі професійно-творчі та професійно-особистісні властивості майбутнього вчителя образотворчого мистецтва.

Достатньої підстави для застосування диференційованого навчання надає тенденція до нарощування кількості «мов» сучасної художньої культури, що втілюється в нових видах мистецтва, нових засобах художньої виразності. Очевидно, що тенденція розширення мови художньої культури буде зберігатися й у майбутньому. Тож, у процесі фахової підготовки майбутніх учителів образотворчого мистецтва важливо не тільки закласти міцний фундамент теорії та практики, а й задати певний алгоритм художнього саморозвитку студента та розвитку його художньо-творчих здібностей шляхом застосування різнорівневих завдань, урізноманітнення засобів практичної підготовки студентів.

Отже, нині диференційований підхід та внутрішня диференціація навчання в межах предметної підготовки студентів художньо-графічних факультетів відіграють роль провідного твірного механізму, що дозволяє розкрити внутрішні резерви фахової підготовки студентів, забезпечує індивідуально-особистісну спрямованість навчального процесу та сприяє розкриттю пізнавально-творчих здібностей, таланту та обдарувань майбутніх учителів образотворчого мистецтва.

Перспективу подальших наукових пошуків убачаємо в розробленні механізмів реалізації диференційованого підходу в предметному середовищі окремих навчальних дисциплін факультету мистецтв, створенні науково-теоретичного підгрунтя для оптимальної інтеграції психолого-педагогічних здобутків та мистецької освіти.

\section{Література}

1. Гончаренко С. У. Український педагогічний словник / Семен Устимович Гончаренко. - Київ : Либідь, 1997. - С.95. 2. Дидактика средней школы / под ред. М. Н. Скаткина. - Москва : Просвещение, 1982. - 319 с. З. Закон України «Про вищу освіту» (Редакція від 01.01.2015, підстава 76-19) [Електронний ресурс]: Режим доступу : http://zakon4.rada.gov.ua/laws/show/1556-18. - Назва 3 екрану. 4. Лингводидактический энциклопедический словарь / под ред. А. Н. Щукина. - Москва : Астрель : Хранитель, 2007. 77 с. 5. Методика навчання мистецтва у початковій школі: [посібник для вчителів]/ [Л. М. Масол, О. В. Гайдамака, Е.В.Бєлкіна та ін.]. - Харків : Ранок, 2006. - 256 с. 
6. Неменский Б. М. Педагогика искусства : [монография] / Б. М. Неменский. - Москва : Просвещение, 2007. - 256 с. 7. Панкратова Л. И. Формирование композиционного мышления студентов факультета педагогики и методики начального образования вуза на занятиях изобразительным искусством: автореф. дисс. на соискание ученой степени канд. пед. наук : спец. 13.00.02 «Теория и методика обучения» / Л. И. Панкратова. - Москва, 1998. - 21 с. 8. Талызина Н. Ф. Формирование познавательной деятельности учащихся / Наталия Федоровна Талызина. - Москва : Знание, 1983. - 96 с.

УДК 378

Ірина Лов’янова, Дмитро Бобилєв

\section{СИСТЕМА ПРОФЕСІЙНО СПРЯМОВАНИХ УМІНЬ СТУДЕНТІВ ПРИ НАВЧАННІ ФУНКЦІОНАЛЬНОГО АНАЛІЗУ}

Лов’янова І. В., Бобилєв Д. Є. Система професійно спрямованих умінь студентів при навчанні функціонального аналізу.

У статті на основі зіставлення, порівняння, узагальнення наукової інформації та за результатами аналізу структурно-логічної схеми та змісту пропедевтичного курсу функціонального аналізу виокремлено професійно спрямовані вміння, які доцільно формувати в цьому курсі. Розглядаються основні вимоги щодо організації навчання функціонального аналізу майбутніми вчителями математики на основі упровадження методичної системи професійно спрямованого навчання, яка сприяє формуванню у студентів професійно орієнтованих умінь.

Ключові слова: професійно спрямоване навчання, професійно спрямовані вміння, функціональний аналіз, учителі математики.

Ловьянова И. В., Бобылев Д. Е. Система профессионально направленных умений студентов при обучении функциональному анализу.

В статье на основе сопоставления, сравнения, обобщения научной информации и по результатам анализа структурно-логической схемы и содержания пропедевтического курса функционального анализа выделены профессионально направленные умения, которые целесообразно формировать в этом курсе. Рассматриваются основные требования к организации обучения функциональному анализу будущих учителей математики на основе внедрения методической системы профессионально направленного обучения, которая способствует формированию у студентов профессионально ориентированных умений.

Ключевые слова: профессионально направленное обучение, профессионально направленные умения, функциональный анализ, учителя математики.

Lovyanova I. V., Bobyliev D. Ye. The system of professionally oriented skills of students in the process of functional analysis training.

On the basis of the comparison, contrast, generalization of scientific information, analysis of structural and logical schemes and content of propaedeutic course of functional analysis professional oriented skills, which are nessecary to form within this course were selected. The basic requirements to the organization of the functional analysis training of future Mathematics teachers on the basis of introduction of methodical system of professionally oriented training which promotes students' professionally oriented skills were examined.

Key words: professionally oriented training, professionally oriented skills, functional 